\title{
Publisher Correction: Exploiting intervalley scattering to harness hot carriers in III-V solar cells
}

Hamidreza Esmaielpour (D), Kyle R. Dorman, David K. Ferry, Tetsuya D. Mishima, Michael B. Santos, Vincent R. Whiteside (D) and lan R. Sellers (D)

Correction to: Nature Energy https://doi.org/10.1038/s41560-020-0602-0, published online 20 April 2020.

In the version of this Article originally published, in Fig. $4 \mathrm{a}-\mathrm{c}$, in the legends, the red dashed lines were mistakenly labelled as ' $E_{\mathrm{fn}}(\mathrm{eV})$ '; they should have been labelled ' $E_{\mathrm{fp}}(\mathrm{eV})$ '. All versions of the Article have been corrected.

Published online: 29 July 2020

https://doi.org/10.1038/s41560-020-00679-4

๑ The Author(s), under exclusive licence to Springer Nature Limited 2020 